\title{
THE
}

\section{Teacher motivations for digital and media literacy: An examination of Turkish educators}

Renee Hobbs

Harrington School of Communication and Media, University of Rhode Island, hobbs@uri.edu

Sait Tuzel

Follow this and additional works at: https://digitalcommons.uri.edu/com_facpubs

The University of Rhode Island Faculty have made this article openly available.

Please let us know how Open Access to this research benefits you.

This is a pre-publication author manuscript of the final, published article.

Terms of Use

This article is made available under the terms and conditions applicable towards Open Access

Policy Articles, as set forth in our Terms of Use.

\section{Citation/Publisher Attribution}

Hobbs, R. \& Tuzel, S. (2017). Teacher motivations for digital and media literacy: An examination of Turkish educators. British Journal of Educational Technology 48(1), 7 - 22. DOI: 10.1111/bjet.12326 
PRE-PUB COPY

CITE AS:

Hobbs, R. \& Tuzel, S. (2017). Teacher motivations for digital and media literacy: An examination of Turkish educators. British Journal of Educational Technology 48(1), 7 - 22. DOI: 10.1111/bjet.12326

\title{
Teacher motivations for digital and media literacy: An examination of Turkish educators
}

\begin{abstract}
Although we live in a global society, educators face many challenges in finding meaningful ways to connect students to people of other cultures. This paper offers a case study of a collaboration between teachers in the US and Turkey, where $7^{\text {th }}$ grade students interacted with each other via online social media as a means to promote cultural understanding. In a close analysis of a single learning activity, we found that children had opportunities to share ideas informally through social media, using their digital voices to share meaning using online writing, posting of images and hyperlinks. This study found that students valued the opportunity to develop relationships with each other and generally engaged in sharing their common interests in Hollywood movies, actors, celebrities, videogames and television shows. However, not all teachers valued the use of popular culture as a means to find common ground. Indeed, teachers had widely differing perspectives of the value of this activity. Through informal communication about popular culture in a "Getting to Know You" activity, students themselves discovered that their common ground knowledge tended to be UScentric, as American students lacked access to Turkish popular culture. However, the learning activity enabled students themselves to recognize asymmetrical power dynamics that exist in global media culture, where information and entertainment flows are primarily one-way in nature and perceptions about the value of popular culture are contested.
\end{abstract}

Keywords: Student voice, popular culture, social media, media literacy, digital literacy, global education, Turkey, United States 


\section{Introduction}

Undoubtedly, Web 2.0 technologies enable learners to travel across time and space. In her review of the ICT literature since 2004, Loveless (2011) identified the advances in pedagogical design thinking and sensitivities towards sociocultural approaches to ICT in education as significant trends. In the past two decades, all around the world, most general accounts of education have emphasized that schooling needs to take account of the multiple channels of communication and media now in popular use (Lee, Lau, Carbo \& Gendina, 2012; New London Group, 1996). In the context of English language arts education, in particular, the traditional print-based concepts of literacy, text, and meaning are becoming strategically displaced as teachers and school leaders begin to recognize that people now use language, images, sound, and multimedia for everyday purposes of expression and communication and that the relevant associated competencies must be part of elementary and secondary education (Hobbs, 2010; Tüzel, 2013a; Tüzel, 2013b). Undoubtedly, literacy today is "situationally specific" and "dynamically changing" (Coiro, Knobel, Lankshear, \& Leu, 2008 , 5) all around the world. In Turkey, for example, there has been a significant investment in providing access to digital technology in elementary and secondary schools to support teaching and learning (Kurt, 2013; Ünal \& Öztürk, 2012).

Yet, despite an array of global education initiatives, the potential of digital media to support educational innovation in the elementary and secondary education context is still largely unrealized, especially in relation to social studies and foreign language education. While researchers from all parts of the world have been aiming to advance comparative and international civic education, the use of digital media texts, tools and technologies as a tool to promote student civic voice in relation to global education and language learning in the context of contemporary life is still underdeveloped. Bazalgette (2008) has lamented the fact that, even with the plethora of international academic conferences and scientific meetings, there has been little truly global collaborative work in digital and media literacy education that involves elementary and secondary educators from two or more countries.

In this paper, we present a case study of an international collaboration involving middle school teachers from two countries, working in collaboration with the authors, to design and implement an intercultural learning experience that brings together Turkish and American students in Grade 7 using digital and social media. The goal of the initiative was designed to help students (a) develop confidence in expressing themselves with people using online social media, (b) promote cultural knowledge and critical thinking about media and popular culture, and (c) advance global understanding between middle-school students in Turkey and the United States. By linking together subject-area instruction in social studies and foreign language education in English, this initiative broke new ground as teachers and learners explored how to use the power of social media for sustained social and cultural interaction over a period of six weeks. Evidence from this case study demonstrates that the use of digital and social media to activate children's voice requires sensitivity to differential perceptions of the value of popular culture among teachers as well as robust appreciation of the asymmetries and inequalities still inherent in global information and entertainment flows.

\section{Cross Cultural Learning Goes Digital}

Globalization and digital technology have combined to open up cultures to a fastpaced world of change and educators have been inspired to bring the world into their classrooms, enabling students to have a civic voice (Hobbs, 2010). Although traditional global pen pal programs have been in place in the U.S. since the 1920s, (Hill, 2012), in the years after the 9/11 terrorist attack, some educators began exploring with how to promote student voice and global understanding to bring together Americans and peoples of the 
Middle East through cross-cultural communication learning experiences. To increase students' experiences with people different from themselves, such projects may include work with international students from local universities, immigrant organizations in the community, service learning projects, exchanges through e-mail or videos, and taking students overseas (Merryfield, 2002). In these projects, teachers may ask students to use email or online communication to develop keyboard skills, share poetry, report writing, and journal writing - all fundamental dimensions of literacy education.

The rise of social media has made it easier for teachers and students from diverse cultures meet and work together. Teachers may emphasize cross-cultural learning experiences as a transformative way to teach "children to care and make a difference in the world while simultaneously trying to make a difference in the world" (Aldridge \& Goldman, 2007, p.78). In a dissertation study of Grade 6 American students who participating in letterwriting to children in Indonesia via email, students' consciousness about people living in another culture, practicing another religion, and engaging in a different lifestyle was changed. Through the email interactions, children learned a great deal about stereotypes they unknowingly held about others (Hill, 2012). Such efforts can be useful not only to students, but to teachers as well. Cross-cultural projects may not only promote confidence in selfexpression, but may also promote the development of reflective-synthetic knowledge, a concept articulated by Kincheloe (2004) who described it as a process that advances student voice while revealing to both teachers and students the often hidden assumptions about the nature of knowledge itself.

\section{Digital Literacy for Global Education}

The term digital literacy has begun to emerge to reflect the broad constellation of practices that are needed to thrive online (Rheingold 2012; Gilster, 1999). Most conceptualizations focus on the pragmatic skills associated with the use of digital tools and texts. As Greenhow, Robelia and Hughes (2011) note, "Digital literacy includes knowing how and when to use which technologies and knowing which forms and functions are most appropriate for one's purposes" (250). But other definitions explicitly conceptualize digital literacy as a broader literacy competency, including the ability of learners to access, analyze, create, reflect and take action using the power of communication and information to make a difference in the world (Hobbs, 2010).

Even more broadly, across Europe, Asia, South America and Africa, the term media and information literacy (MIL) has been recognized as a means to foster more equitable access to information and knowledge; promote freedom of expression; advance independent and pluralistic media systems; and improve the quality of education. By empowering "citizens to understand the functions of media and other information providers, to critically evaluate their content, and to make informed decisions as users and producer of information and media content," media and information literacy, while sometimes seen as separate and distinct fields, are conceptualized as a combined set of competencies necessary for life and work today (UNESCO, 2013, 16).

Only a few school-based projects have aimed to advance learner voice by connecting youth from across communities to promote cultural understanding through media literacy. For example, elementary educators in the U.S. used a variety of media literacy practices, including viewing and discussion, critical analysis of images, film/media production and interaction with youth from Kuwait as a way for children to gain knowledge of the peoples (Hobbs et al, 2011a; Hobbs et al, 2011b). By talking about how news, media and popular culture embed stereotypes about culture and values, children as young as eight and nine were able to recognize that media messages (including photographs, movies, websites and books) 
can be critically interrogated. Media analysis and production activities can help build critical thinking and activate student voice while simultaneously advancing knowledge and language skill development (Hobbs, 2007; Tüzel, 2012a; Tüzel, 2012b). For example, during the process of an action research project, a Turkish teacher who integrated media literacy education into language arts, using popular culture texts (film, TV serial, magazine etc.) for learning, increased students' levels of media literacy, critical thinking and language skills; in addition to expanding textual awareness, this learning activity shifted learners'

conceptualization of literacy from the alphabetic to the multimodal (Tüzel, 2012a).

Social media and other virtual environments have the potential to play a role in terms of cultivating intellectual curiosity and advancing civic voice in conjunction with learning about people and cultures around the world. Intergroup dialogue (generally involving young adults) has been shown to be effective in combatting negative stereotypes and prejudices about countries and cultures, promoting tolerance and intercultural acceptance (Hurtado, 2005 ) and a growing number of organizations are bringing global dialogues to college students using digital media (Soliya, 2014). However, historical asymmetries of status and power between groups may affect the quality of learning for the majority/empowered and minority/disempowered group members (Cikara, Bruneau \& Saxe, 2011).

Teacher-initiated activities with digital tools, texts and technologies may activate a range of pedagogical approaches to learning that can vary on a continuum from more to less formal. Greenhow and Lewin $(2015,13)$ noted "the complexities of teasing out formal and informal attributes of learning," urging scholars to avoid the limitations of reducing formal and informal learning to binary opposites when exploring the use of social media in education. Informal learning activities can help build critical thinking while simultaneously advancing a sense of civic agency and participation in local, national and international issues. For example, the Global Kids program serves youth in Washington DC and New York with programs that encourage youth to listen and respond with respect to those with whom they disagree, considering similarities and differences in the way people experience and address issues of concern. Through creating media, developing community campaigns and participating in public events, youth who participate in this after-school program broaden communication and problem-solving skills while increasing their knowledge of world affairs and the democratic process, exploring issues like human rights, climate change, civic engagement, and access to education (Global Kids, 2015). While such work, supported by non-profit organizations with funding from charitable philanthropies, is highly valuable, there is considerably less evidence in the scholarly literature about similar practices of informal learning that may occur in the ordinary context of a middle-school classroom.

Accordingly, based on this review of the literature, we report the results of a single school-based instructional activity that aimed to activate student voice and promote global awareness. In exploratory research, we examine these research questions: How did US and Turkish learners and teachers experience the cross-cultural communication project? What were the affordances and limitations of using a social media exchange activity for activating student voice and building cross-cultural understanding?

\section{Methods}

This section summarizes the case study method we employed to explore the use of a private online social network to facilitate co-learning between middle-school teachers and students in the United States and Turkey. The project was designed to enable American and Turkish students to (a) develop confidence in expressing themselves with people using online social media, (b) promote cultural knowledge and critical thinking about media and popular culture, and (c) advance global cultural understanding between middle-school students in 
Turkey and the United States. By linking together subject-area instruction in social studies and foreign language education in English, this initiative helped both teachers and learners explore how to use the power of an online social network for sustained social and cultural interaction.

A six-week online cross-cultural learning experience program using a private online social network was developed and implemented by researchers in collaboration with The George School faculty (a pseudonym for a private school in Northern California) and the faculty of The Blossom School (a pseudonym for a private school in Western Turkey). Close analysis of one lesson provided us with an opportunity to gather exploratory data about the way teachers and students perceive the value of using one's voice to encounter people from another culture and learn about their lives, experiences and interests.

\section{Sample}

A total of 84 children between the ages of 12 and 14 participated in the project. A middle-school history teacher at George School and his 43 Grade 7 students worked with five English teachers at Blossom School in Turkey, along with two M.A. students in Education, and 41 Grade 7 Turkish students enrolled in an English class. Additional demographic information about the community contexts is provided below.

\section{Research Process}

In this study, interviews, documents, observations, video recordings and students' work samples were used to analyze the quality of the learning experience. The researchers conducted interviews with both teachers and students before, during and after the implementation to record the thoughts and opinions of the teachers and students. The researchers paid special attention to changes in students' comments about the other culture. The authors also focused on the reasons for the posts and interactions of the students. Therefore, the authors tried to make an extensive analysis of the causes of events and situations (Ellet, 2007, 19). Data triangulation provides support for reliability as different data collection tools including interviews, observation and written and visual document analysis in the social network were used. In both schools, students participated in the project and performed the tasks requested of them during the implementation on a voluntary basis.

\section{Context of the Study}

Working collaboratively, Turkish and American teachers and the researchers prepared a curriculum consisting of four lesson plans. This curriculum was put into practice over the course of six weeks. Before this process began, the researchers held four online meetings with both Turkish and American teachers during two weeks. During these meetings, the plans for the project were made, the students registered in the system, and their personal profiles were created.

Of the many social media platforms available, Ning (http://www.ning.com) is a service that allows users to create their own social networking site. Ning was selected as the online platform to host the global collaboration for several reasons. First, since there is a 10hour time difference between California and Turkey, the researchers needed a platform that would support both asynchronous and synchronous interaction. Moreover, securing the privacy of the students was vital for both teachers and researchers. Ning is a closed social network in which no one can view students' pages without the approval of system administrators. Each student was able create personal pages and post digital files to share in media galleries; small groups of Turkish and US students were also able to interact with each other in threaded discussion groups. 
California School. The George School is located in the North Bay region of the San Francisco Bay Area in the United States. It is an independent private school with an annual tuition fee of $\$ 28,000$. The school attracts students from a community of about 60,000 residents who are predominantly wealthy to upper middle class, with a median family income of $\$ 98,000$ and a largely White population. Many of the residents work in professional fields, including computer science, entertainment, media, banking, healthcare, and $86 \%$ of the population have a Bachelor's degree or higher. Also, there is little economic diversity in this community, with only $10.7 \%$ of residents living in poverty. Fewer than $10 \%$ of residents are Asian and European immigrants (U.S. Census 2010).

The George School has long embraced new technologies and literacies and the faculty has integrated media literacy into their elementary and middle-school curriculum for over ten years. Many of the parents who send their children to the school are themselves Google executives. Teachers at the George School were well-aware of the value of digital and media literacy to activate student voice in relation to global education, which was the term they themselves used for activities that helped students gain cultural competence and intercultural sensitivity. Typically, however, the faculty did not use digital media as part of their global education curriculum; this pilot project was a new experience for them.

The "California - Turkey" digital media activities at George School were integrated into the $7^{\text {th }}$ grade history class and functioned as social studies curricular activities. For Mr. Herbert, the history teacher, the Middle East was a distinct unit of instruction in his curriculum. He believed that the opportunity to directly interact with students from Turkey might reduce students' prejudices and stereotypes about the Middle East. This belief motivated his interest in the value of the online learning activities; he taught the curriculum based on his belief that students from different cultures can learn from each other. As a veteran teacher with over 12 years of experience, Mr. Herbert's broad perspective and insight on media and digital literacy combined with his comfortable use of digital media and ICT technology; this helped him to guide students in making deep analyses of the activities they engaged in over the six-week period.

Turkish School. Like The George School, Blossom School is also a private school, dependent on tuition fees from families who pay for $\$ 12,000$ (US) annually their children to attend the school. Nearly half of students' parents are faculty member $(45 \%)$ with other parents in careers as physicians, engineers, pharmacists or other high-income professions. Of the participating students' parents, 71\% have a bachelor's degree or higher degrees. The Blossom School is located in Canakkale, a city located in the furthest point in the west of Turkey, which lies in both Asian and European parts of the country. The city has a population of approximately 116,000 and is not highly industrialized. Half of the city's population consists of university students or workers. Of the population, $23 \%$ has a bachelor's degree or higher, a rate which is far above the national average of $8 \%$ (TurkStat 2013).

Unlike at The George School, the digital literacy activities at the Blossom School were not intended as "in-classroom" activities. Students performed this work as an extracurricular activity, supervised by five English teachers with between 3 to 19 years of teaching experience. When asked to describe their motivation for participating in this exploratory project, teacher motivations varied: some teachers primarily valued the opportunity for learners to improve English language skills while others valued the opportunity to promote cultural competence and global understanding. For example, Mr. Ozturk, Mr. Yildirim and Miss Yildiz said that the project was an opportunity for students to 
improve their competence in English. During the project, they focused on students' communication skills in English, grammar mistakes and other similar issues rather than the informational content of the activities. Moreover, during the study, they also were frustrated that American students' written expression did not always conform to grammatical rules, as children did not always use standard English in their threaded discussions. Mr. Yaman and Miss Ocak were more interested in the cultural interaction and global understanding dimensions of the project. During the practices, they encouraged students to present their own culture and values and try to understand American culture. They also suggested cultural materials and content that children could share using the Ning to help American learners appreciate Turkish culture.

Unlike at The George School, the faculty of the Blossom School did not have any prior experience with the pedagogy of media and digital literacy, particularly in relation to Tyner's (1998) distinction between representational literacies (where the focus in on examining how digital media texts are constructed) and tool literacies (where the focus is on the use of digital tools for teaching and learning). As a result, at the Blossom School, projectors, computers and tablet PCs are all available to be used by the teachers and students. However, these tools are only used in context of education with media and technology, with a primary emphasis on content delivery. In meetings with the teachers prior to the implementation, we learned that teachers did not have any ideas about teaching about media and digital technology. The concept of media and digital literacy was unfamiliar to them. Although teachers participated in a webinar based on the principles of media literacy before each of the activities, the researchers observed that the Turkish teachers were not fully engaged during these webinars. Because this was to be an extra-curricular activity, we decided to engage the services of master's in education students who were students of the second author and familiar with the pedagogy of digital and media literacy education. During after-school times, the graduate students assisted both teachers and students in preparing videos and screencasts to be used online and performing other activities to support student learning.

\section{Curriculum Development}

Using the model of a university-school partnership, Turkish and American middleschool teachers worked collaboratively with researchers to prepare four lesson plans based on the principles of media literacy (NAMLE, 2008). University school partnerships provide important supports to educators who aim to explore innovative instructional practices in digital and media literacy education (Moore, 2013). The development of four lesson plans enabled students to share information about culture and values of their family and community, learn more about the history, cultural practices and social norms of these two cultures, and critically analyze popular entertainment media representations of culture and values. Table 1 provides a summary of the complete curriculum as aligned with elements from the five-part AACRA definition of digital and media literacy (Hobbs, 2010).

Researchers and teachers were careful to include a balance of learning experiences that encouraged students to access, analyze, create, and reflect on information and ideas in the context of the global co-learning experience. Before implementation of the curriculum, the researchers held four online planning meetings with both Turkish and American teachers where a timetable and learning process was established and the students were pre-registered in the social media platform.

Table 1 here 


\section{Findings}

In order to focus on how middle-school students developed confidence in expressing themselves using online social media by finding common ground with peers from halfway around the world, we describe and analyze the implementation of only the first lesson. In a close analysis the "Getting to Know You" learning activity, children had opportunities to share ideas informally through social media, using their digital voices to share meaning using online writing and posting of images. While students valued the opportunity to develop relationships with each other by sharing their common interests in Hollywood movies, actors, celebrities, videogames and television shows, teachers had widely differing perspectives of the value of this activity. Through informal communication about popular culture, students themselves discovered that their common ground knowledge tended to be US-centric, as American students lacked access to Turkish popular culture. The learning activity foregrounded the asymmetrical power dynamics that exist in global media culture where information and entertainment flows are primarily one-way in nature and perceptions about the value of popular culture are contested. As is appropriate with case study research, we interweave interpretation with narrative description.

\section{Learning to Talk Across Cultures}

Lesson 1, "Getting to Know You," was an ice breaker activity, aimed to introduce students to each other and help them develop confidence in interacting with others as they gained familiarity with the Ning social media platform. Through this activity, students began to discover their similarities and differences. Teachers asked their students to share three things about themselves and their culture in one week; they did not limit students about the structure, length or content of their posts. The 84 participating Turkish and American students could share a sentence, photo, video or any other thing they wanted to share. In order to support students in the process of relationship formation, students were assigned to one of seven groups (with six students in each group). The small group structure made it easier for students to read and follow each other's posts and respond to each other personally. Students shared 391 posts during the implementation of Lesson 1, for an average of 4.6 posts per student during the week. Some of these posts were questions designed to engage another student while others were just aimed at presenting themselves and their own culture.

Students demonstrated significant interest in participating in this activity. However, in the first few days, they sometimes had difficulty responding to questions or commenting on each other's posts. Two main reasons seem evident: most importantly, Turkish students were expressing themselves in a foreign language while U.S. students were communicating in their native language. Also, the ten-hour time difference between The Blossom School and The George School made it initially difficult for students to understand how to follow each other's comments. It took a few days for students to understand how to navigate and read the posts as Turkish and American students each posted comments at different times of the day (at school) and the evening (at home).

The novelty of "talking" across space and time was fascinating to many young students. Early on, a student from The George School noted:

\section{U.S. STUDENT 1}

This is kind of a random comment, but I think that it is kind of mindblowing when you think about the fact that two people can be sitting at a computer, typing on the same forum, but for one person it is the early morning (it is 10:40 in the morning as I type this) and for the other it is late at night (I think it is 8:40 at night in Turkey). 
Students enjoyed the opportunity to interact socially and share information about their own culture. In general, students preferred to write simple sentences. However, students also uploaded photos and videos of themselves, friends and family, favorite places and food. Some students shared links to music, movie series and computer games they loved, asked what their peers thought about them, or responded to similar questions. The researchers observed that the students visited their profiles and the discussion board many times during the week when Lesson 1 was being implemented. Student behavior reflects Stern's (2008) observation about the authentic personal pleasure young adolescents experience using social media for self-presentation and peer validation.

Analysis of the 391 posts that students shared during this activity reveals a wide range of subjects. Some of these subjects are about ordinary elements of daily life, community and environment, favorite activities, school work, information about their parents and siblings and their relationships with them, countries they visited and favorite foods. The students were very open to interaction and curious about each other's lives. They wanted to inform the students with whom they were talking and elaborate on the subjects of their conversations. Notice the clear evidence of relationship development displayed in the exchange below:

U.S. STUDENT 2

My brother is 16 . How old is your brother?

\section{TURKISH STUDENT 1}

My brother is 8 years old. He is younger than me. I've got dogs too. I've got 2 dogs. One of my dog [sic] have 3 puppy. They are very sweet I can share their photo maybe. What about your dogs? Can you share their photos?

The activity clearly enabled students to build trust and respect and it may also have prevented students from approaching each other based on stereotypes, helping them to see each other as individuals. Within a day or two, the American students, who thought that they were interacting with Middle Eastern people, realized that the students with whom they were talking were individuals with families, personal lives and hobbies. They stopped seeing the students at the other school as a group of foreigners and started to see them as individuals. It was certainly the same for Turkish students, too, who may have had stereotypes about American culture.

\section{Finding Common Ground through Media and Popular Culture}

More than two-thirds of all the social interactions during Lesson 1 focused on the discovery of common ground through shared interests in mass media and popular culture. Posts included information and opinions about American mass media, as students discussed a variety of actors, movies, TV series video games, popular books, music and similar subjects. In these dialogues, many students discovered that they were interested in the same types of popular culture products as the students in the other country. They were excited by the discovery of their common interests in music, fashion, gaming and movies.

Thanks to these dialogues, children realized that although they lived in different parts of the world, they admired the same singers and actors, watched the same movies and TV series and played the same computer games in their free time. They were excited to recognize that popular culture was a kind of common global culture. The informal quality of language and expression used on the social network, plus the amount of conversation about media and popular culture, was somewhat unnerving to Turkish teachers of English language who were 
unfamiliar with the pedagogy of media literacy education. To illustrate this point, consider this exchange between Turkish and American teens:

\section{TURKISH STUDENT 3}

Do you know Mythbusters that show is really good.

U.S. STUDENT 4

OMG! That show is amazing!!!!!

\section{U.S.STUDENT 6}

Yeah I used to watch that show and want to try doing the things they did. It was a little dangerous though.

TURKISH STUDENT 5

Yea, they blow up everything: D

U.S. STUDENT 3

Hahahahaha, Do you know the show "Top Gear"?

\section{TURKISH STUDENT 3}

Yea, It's an American show, right?

\section{U.S. STUDENT 3}

It's actually from the UK but there is an American version and lots of other versions although the original one is from the UK

\section{U.S. STUDENT 6}

No, my parents won't let me :(

During this activity, students developed confidence in expressing their voice by sending posts, interacting and asking questions. While most used grammatically correct English, others used some of the linguistic conventions of text messaging, including emoticons and excessive punctuation in their informal writing. Students discovered that they had valuable knowledge that was of interest to others. In particular, American students were surprised to see so many similarities between the Turkish students and themselves.

\section{Conflicting Values about Popular Culture among Teachers}

Teachers had differing perceptions about the value of Lesson 1, which encouraged children to use social media as an informal sharing opportunity to encounter each other as human beings. Mr. Herbert, from George School, was very happy that his students started to learn about the personal interests of children who growing up in Turkey. He was pleased that students could activate their out-of-school knowledge about sports, media, music and family life in interacting with Turkish middle-school students through social media. Because students know so little about daily life in Turkey, Mr. Herbert believed that his students were learning from their Turkish peers to "question the prejudices and stereotypes conveyed by the American mass media" about the people and cultures of the Middle East. At the end of the first week of the activity, he noticed students' attitude shifts during classroom discussion and he focused on the changes he observed in the prejudices of the students. He described how students started to question their knowledge about the Middle East and Turkey. 
By contrast, teachers at the Blossom School in Turkey had an entirely different perspective about the value of Lesson 1. Turkish teachers had hoped that the project would be an opportunity to promote Turkish culture and values. For this reason, they were unhappy that in Lesson 1 students were mostly discussing American popular culture. Teachers encouraged their students to talk about elements of the Turkish culture such as traditional Turkish coffee, carpets, food, geography, history and hospitality. Despite these admonitions, the Turkish students kept on posting comments about American mass media and pop culture. In an interview, Mr. Yaman expressed this concern, "In this project, we mainly wanted the students to promote their lifestyle and culture to the American students. I believe that they should focus on Turkish culture, but they mostly talked about American movies and celebrities." One of the Turkish graduate students who helped the Turkish teachers with this project said, "I witnessed that teachers were uncomfortable with students' using social media and creating video, especially when such activity led to the production of popular culture texts that threatened national school-sanctioned curricula and the teachers' authority."

These findings are aligned with work by Moore (2013) who reports various sources of anxiety among elementary and secondary teachers concerning the inclusion of popular culture in the classroom. Although informal learning in formal educational contexts can be highly valuable, this study illustrates that experiences with using one's voice in a social media network may "shape young people's knowledge construction in unexpected ways," inspiring teachers to "structure informal practices that were not perceived to hold a legitimate place in formal education" (Greenhow and Lewin, 2015, 18).

\section{Discovering Asymmetries in Access to Media and Popular Culture}

Turkish students were both excited to discover their common interests and disappointed to see that the American students had such limited knowledge about Turkish culture and media. Some Turkish students asked their American peers about their familiarity with particular Turkish actors and musicians. Turkish children were curious if American students were familiar with the best and most famous Turkish movies and TV series. However, they did not get any responses. Because of the historical development, size and scale of the U.S. media industry, Americans have less access to global popular culture than people from other nations (Crothers, 2013). For example, only seven cities in the United States carry the television network Al Jazeera America (Cassara, 2014).

When the Turkish children were interviewed, many revealed their disappointment that the conversations about popular culture were a "one-way street" with an exclusive focus on American media from Hollywood and Silicon Valley. The asymmetry of knowledge about popular culture was at times frustrating to the Turkish students. For example, one Turkish student said, "We know about the American TV series, movies and singers. Justin Bieber is very famous and handsome both for them and for us. But there are also singers in our country who are as handsome and talented as Justin Bieber, yet they do not know about them."

Over time, American children also grew more gradually aware of the asymmetry problem, and by the end of the six-week curriculum, both groups had increased their awareness of how some asymmetries in their online relationship that were the result of structural, economic and political differences in the global media system. Mr. Herbert, the American teacher, was supportive of the children's discovery of the problem of asymmetrical access. According to the teacher, for some students, it was a shock to learn that, despite their privileged status as American school children enrolled in a private school, they missed having access to global information and entertainment coming from Turkey. It was an eye-opening experience that introduced children to the intersection of individual and institutional dynamics at work in relation to cultural imperialism (Schiller, 1969) where the pursuit of 
commercial interests by US-based transnational corporations undermined the cultural autonomy of countries around the world. At the end of the learning experience, one American student wrote, "I learned that the world outside of America is actually pretty similar to ours, and that different people view different things in very different ways. But I noticed that I have no idea about Turkish cultures and life. I learned a lot from this, and it was really great!"

Media globalization has created new kinds of inequalities between nations in relation to media production and global distribution that reflect wider political and economic problems of dependency (Boyd-Barrett, 1998). The rise of media globalization, which emerged at the beginning of the $20^{\text {th }}$ century from the global export of Hollywood film, has now expanded to include music, video games, advertising, merchandising and celebrity culture. We did not expect to find that, as the use of a private online social network empowered student voice, it also enabled students to develop a deeper understanding of the global flows of entertainment and information that shape how cultural products are exchanged and experienced. We did not expect that youth would learn to use their digital voices in interacting with foreign peers by finding common ground in the pleasures of movies, television shows, videogames, and popular music. We did not expect for this practice to be controversial with classroom teachers. Through a close analysis of an activity where young teens interacted informally with each other to find common ground, this study is the first to demonstrate that, through interacting with global peers, even young teenagers can begin to recognize the nature of one-way information flows that are driven by the global media system where U.S. music, movies and videogames dominate.

\section{Discussion}

The opportunity to talk across the limitations of time and space can be transformative. This paper has offered a case study of a collaboration between teachers in the US and Turkey, where $7^{\text {th }}$ grade students interacted with each other informally via online social media as a means to activate student voice and promote cultural understanding. In the context of this middle-school global learning experience, children had opportunities to share ideas through social media, using online writing, posting of images, and the creation of short films, posters and electronic comic books. We have shown that there is educational value in the informal use of social media with young adolescents, whose in-school use of social media in the context of social studies and foreign language education has not yet been researched widely. For young adolescents, it may be empowering to discover that people from far-off lands have families, pets, friends, and all the ordinary joys, trials and tribulations of growing up. The opportunity to use social media for ordinary conversation - finding common ground - may have benefits that include but go far beyond the mastery of English grammar and usage.

Digital media are useful for crossing borders of all kinds. While students valued the opportunity to develop relationships with each other by sharing their common interests in Hollywood movies, actors, celebrities, videogames and television shows, teachers had widely differing perspectives of the value of this activity. While we anticipated that this project would enable us to explore how middle-school students navigate geographic and cultural borders, this research demonstrates that teacher attitudes about popular culture represent another key fault line that may either support, deepen or limit the value of digital literacy instructional practices, particularly when social media activities are used by students to engage in authentic cross-cultural dialogue. More research will be needed to fully understand the conditions under which students' use of social media to share informal knowledge may inadvertently become a kind of power wedge between students and adults.

This study has implications for the professional development of educators with interests in student voice. When students are able to freely express themselves, they will 
inevitably reveal their authentic and deeply-felt attachments to mass media and popular culture. Teachers who may be ambivalent, conflicted or even hostile to popular culture in the classroom and professional development must address this issue in the context of digital learning. For this reason, Hagood, Alvermann and Heron-Hruby (2010) have suggested that teachers who participate in carefully designed long-term professional development programs should become comfortable in integrating popular culture texts into their curricula. According to Alvermann $(2012,218)$, "that such identity constructions frequently become visible through films, music, rap lyrics, and so on is yet another reason why popular culture texts have a place in a school's curriculum and its classrooms." Of course, there may be valid reasons for why some students may not wish to explore their identities through popular culture texts introduced in the school curriculum, especially if (however well intended), the classroom activities colonize or trivialize young people's interests (Burn, Buckingham, Parry \& Powell, 2010).

But because educators have a love-hate relationship with mass media, popular culture and digital media, these attitudes inevitably come into play when digital technologies are used in education (Moore, 2011). We recognize the powerful opportunity that cross-cultural projects may play in promoting a reflective stance among teachers, who may discover the particularities of their values through collaborative projects like the one we describe in this paper. It may be that hidden assumptions about the nature of knowledge itself, including the sometimes rigid and hierarchical positioning of "high" and "low" culture, can be revealed through activities that enable students to bring their lived experience of popular culture and daily life into the classroom (Hobbs \& Moore, 2013). In the design and development of instructional pedagogies that use social media to promote cross-cultural dialogue, teachers may benefit from structured opportunities to reflect on how their attitudes about mass media and popular culture may shape their curriculum choices and use of digital texts, tools and technologies. 


\section{References}

Aldridge, J. \& Goldman, R. (2007). Moving toward transformation: Teaching and learning in inclusive classrooms. Birmingham, AL: Seacoast Publishing.

Alvermann, D. E. (2012). Is there a place for popular culture in curriculum and classroom instruction? [The point position]. In A. J. Eakle (Ed.), Curriculum and instruction (Volume 2, pp. 214-220, 227-228). Thousand Oaks, CA: Sage.

Bazalgette, C. (2008). Media education: International strategies. In U. Carlsson, S. Tayie, G. Jacquinot-Delaunay \& J.M.P. Tornero (Eds), Empowerment through media education: An intercultural dialogue (pp. 235 - 244). The International Clearinghouse on Children, Youth and Media. Goteburg, Sweden: NORDICOM.

Boyd-Barrett, O. (1998). Media imperialism reformulated. In D. Thussu (Ed,), Electronic empires: Global media and local resistance (pp. 157-177). London: Arnold.

Burn, A., Buckingham, D., Parry, B., \& Powell, M. (2010). Minding the gaps: Teachers' cultures, students' cultures. In D. E. Alvermann (Ed.), Adolescents' online literacies: Connecting classrooms, digital media, and popular culture (pp. 183-201). New York: Peter Lang.

Cassara, M. (2014). Al Jazeera remaps global news flows. In Robert S. Fortner, P. Mark Fackler (Eds), The handbook of media and mass communication theory. New York: Wiley Online.

Cikara, M., Bruneau, E. \& Saxe, R. (2011). Us and them: Intergroup failures of empathy. Current Directions in Psychological Science 20(3), 149 - 153.

Coiro, J., Knobel, M., Lankshear, C., \& Leu, D. J. (2008). Central issues in new literacies and new literacies research. In J. Coiro, M. Knobel, C. Lankshear, \& D. J. Leu. (Eds.), The handbook of research in new literacies (pp. 1-22). Mahwah, NJ: Lawrence Erlbaum.

Crothers, L. (2013). Globalization and American popular culture. Lanham, MD: Rowman and Littlefield.

Ellet, W. (2007). The case study handbook. Boston, MA: Harvard Business School Press.

Gilster, D. (1999). Digital literacy. New York: Wiley.

Global Kids (2015). Global Kids: 25 Year of Turning Hope into Action. Retrieved August 16, 2015 from http://storage.cloversites.com/globalkids/documents/GK_PRINT_2.pdf

Greenhow, C., \& Lewin, C. (2015). Social media and education: Reconceptualizing the boundaries of formal and informal learning. Learning, Media and Technology, 1-25. http://doi.org/10.1080/17439884.2015.1064954

Greenhow, C., Robelia, B. \& Hughes, J. (2011). Web 2.0 and classroom research: What path should we take now? Educational Researcher 38(4), 246 - 259.

Hagood, M.; Alvermann, D.E. \& Heron-Hruby, A. (2010). Bring it to class: Unpacking pop culture in literacy learning. New York: Teachers College Press.

Hill, M (2013). International Pen Pals Engaging in a Transformational Early Childhood Project. Doctoral dissertation, University of Alabama, Birmingham. Retrieved August 12015 from http://www.mhsl.uab.edu/dt/2012p/hill.pdf

Hobbs, R. and Moore, D.C. Discovering media literacy: Digital media and popular culture in elementary school. Thousand Oaks, CA: Corwin/Sage.

Hobbs, R. (2010). Digital and media literacy: Connecting classroom and culture. Thousand Oaks, CA: Corwin/Sage.

Hobbs, R. (2007). Reading the media: Media literacy in high school English. New York: Teachers College Press. 
Hobbs, R., Yoon, J. \& Al-Humaidan, R. Ebrahimi, A., Cabral, N. (2011a). Online digital media in elementary school. Journal of Middle East Media, (7) 1 - 23.

Hobbs, R., Cabral, N., Ebrahimi, A., Yoon, J. \& Al-Humaidan, R. (2011b). Field based teacher education in elementary media literacy as a means to promote global understanding. Action in Teacher Education, (33) 144 - 156.

Hurtado, S. (2005). The next generation of diversity and intergroup relations research. Journal of Social Issues, 61(3), 595-610. http://doi.org/10.1111/j.15404560.2005.00422.x

Kincheloe, J. (2004). The knowledges of teacher education: Developing a critical complex epistemology. Teacher Education Quarterly 31(1), 49 - 66.

Kurt, S. (2013). Creating technology-enriched classrooms: Implementational challenges in Turkish education. Learning, Media and Technology, 38(1), 1-17. http://doi.org/10.1080/17439884.2013.776077

Lee, A., Lau, J., Carbo, T., \& Gendina, N. (2012). Conceptual Relationship of Information Literacy and Media Literacy in Knowledge Societies. World Summit on the Information Society. UNESCO Media and Information Literacy. Retrieved from http://bit.ly/1LgJLbL

Loveless, A. (2011). Technology, pedagogy and education: Reflecting on the accomplishment of what teachers know, do and believe in a digital age. Technology, Pedagogy and Education 20(3), 301 - 316.

Merryfield, M. (2002). The difference a global educator can make. Educational Leadership $60(2), 18-21$.

Moore, D. C. (2013). Bringing the world to school: Integrating news and media literacy in elementary classrooms. Journal of Media Literacy Education 5(1): 326-336.

Moore, D. C. (2011). Asking questions first: Navigating popular culture and transgression in an inquiry-based media literacy classroom. Action in Teacher Education 33, 219 230.

National Association for Media Literacy Education (2008). Core principles of media literacy education. Retrieved August 11, 2015 from http://namle.net/publications/coreprinciples/

New London Group. (1996). A pedagogy of multiliteracies: Designing social futures. Harvard Educational Review, 66, 60-92.

Rheingold, H. (2012). Net smart: How to thrive online. New York: Basic.

Schiller, H. (1969) Mass communication and American empire, New York: M. Kelley Publishers.

Soliya (2014). What we do. Retrieved August 15, 2015 from http://www.soliya.net/

Stern, S. (2008). Producing sites, exploring identities: Youth online authorship. In D. Buckingham (Ed.), Youth, identity and digital media (pp. 95 - 117). John D. and Catherine T. MacArthur Foundation Series on Digital Media and Learning. Cambridge, MA: MIT Press.

Tüzel, S. (2012a) Ilköğretim ikinci kademe Türkçe derslerinde medya okuryazarlığı: Bir Eylem Araştırması. PhD Dissertation, Unpublished. Canakkale: Canakkale Onsekiz Mart University.

Tüzel, S. (2012b). Integration of Media Literacy Education with Turkish Courses. Mustafa Kemal University Journal of Social Sciences Institute, 9(18): 81-96.

Tüzel, S. (2013a). Integrating Multimodal literacy Instruction into Turkish Language Teacher Education: An Action Research. Anthropologist, 16(3): 619-630. 
Tüzel, S. (2013b). The Analysis of Language Arts Curriculum in England, Canada, the USA and Australia Regarding Media Literacy and Their Applicability to Turkish Language Teaching. Educational Science: Theory \& Practice, 13(4): 2291-2316.

UNESCO. (2013). Media and Information Literacy: Policy and Strategy Guidelines. Paris. Retrieived August 11, 2015 from http://bit.ly/1LgJLbL

Ünal, S. \& Öztürk, İ. (2012). Barriers to ITC Integration into Teachers' Classroom Practices: Lessons from a Case Study on Social Studies Teachers in Turkey. World Applied Sciences Journal, 18(7): 939-944. 
Table 1

Curriculum for "California-Turkey Cultural Exchange through Social Media" Project

\title{
Key Elements of the Curriculum
}

\author{
Media Literacy \\ Dimensions (AACRA)
}

\section{Getting to Know You}

Share three things about yourself and your culture in one

Access, Create

week. The students can share a sentence, photo, video or any other thing they wanted to share.

\section{Create a Short Film about Your Culture and Life}

Create and share a short video that describes aspects of your daily life.

3. Critically Analyze TV Shows that Feature Students, Teachers and Schools

Compare and contrast two video excerpts from U.S. and Turkish television that are set in high school and feature the representation of high school teachers and students

Access, Analyze, Create, Reflect

\section{Discussion of Current Events}

Read and discuss a news magazine article about the Ukraine

Access, Analyze, Create, Reflect 